\title{
Mitochondrial Calcium Deregulation in the Mechanism of Beta-Amyloid and Tau Pathology
}

\author{
Noemi Esteras * and Andrey Y. Abramov *(D) \\ Department of Clinical and Movement Neurosciences, UCL Queen Square Institute of Neurology, Queen Square, \\ London WC1N 3BG, UK \\ * Correspondence: n.gallego@ucl.ac.uk (N.E.); a.abramov@ucl.ac.uk (A.Y.A.)
}

Received: 31 August 2020; Accepted: 19 September 2020; Published: 21 September 2020

\begin{abstract}
Aggregation and deposition of $\beta$-amyloid and/or tau protein are the key neuropathological features in neurodegenerative disorders such as Alzheimer's disease (AD) and other tauopathies including frontotemporal dementia (FTD). The interaction between oxidative stress, mitochondrial dysfunction and the impairment of calcium ions $\left(\mathrm{Ca}^{2+}\right)$ homeostasis induced by misfolded tau and $\beta$-amyloid plays an important role in the progressive neuronal loss occurring in specific areas of the brain. In addition to the control of bioenergetics and ROS production, mitochondria are fine regulators of the cytosolic $\mathrm{Ca}^{2+}$ homeostasis that induce vital signalling mechanisms in excitable cells such as neurons. Impairment in the mitochondrial $\mathrm{Ca}^{2+}$ uptake through the mitochondrial $\mathrm{Ca}^{2+}$ uniporter (MCU) or release through the $\mathrm{Na}^{+} / \mathrm{Ca}^{2+}$ exchanger may lead to mitochondrial $\mathrm{Ca}^{2+}$ overload and opening of the permeability transition pore inducing neuronal death. Recent evidence suggests an important role for these mechanisms as the underlying causes for neuronal death in $\beta$-amyloid and tau pathology. The present review will focus on the mechanisms that lead to cytosolic and especially mitochondrial $\mathrm{Ca}^{2+}$ disturbances occurring in $\mathrm{AD}$ and tau-induced FTD, and propose possible therapeutic interventions for these disorders.
\end{abstract}

Keywords: calcium; mitochondria; tau; $\beta$-amyloid; MCU; NCLX; VGCCs; glutamate; mPTP

\section{Introduction}

Neurodegenerative disorders, characterised by progressive neuronal loss in specific areas of the brain, nowadays represent one of the biggest medical and social challenges: very few therapeutic strategies are available to slow down the course of these diseases. Aggregation and deposition of misfolded proteins are histopathological hallmarks in these conditions. Among them, $\beta$-amyloid plaques found in Alzheimer's disease (AD) and tau aggregates present in $\mathrm{AD}$, frontotemporal dementia (FTD) and up to other 20 diseases collectively termed tauopathies are one of the most studied [1]. Many actors seem to play an essential role in the pathogenesis of these disorders. The interplay between oxidative stress, mitochondrial dysfunction and calcium ions $\left(\mathrm{Ca}^{2+}\right)$ impairment has been shown to mediate neuronal dysfunction and death in patients' cells and cellular and animal models of $\beta$-amyloid and tau pathology. The present review will focus on the $\mathrm{Ca}^{2+}$ signalling impairment, with a special emphasis on the mitochondrial $\mathrm{Ca}^{2+}$ dysbalance occurring in AD and tau-induced FTD.

\section{Calcium Homeostasis in Neurons}

$\mathrm{Ca}^{2+}$ signalling is a key mechanism in critical events for cell life, from gene transcription or cell growth, to cell-specific mechanisms, such as muscle contraction or egg fertilisation. In neurons, $\mathrm{Ca}^{2+}$ is involved in most aspects of neuronal function: differentiation and migration, synaptic transmission and plasticity, vesicle release, cell death and survival or neuronal-glial communication [2,3]. Indeed, impairment of $\mathrm{Ca}^{2+}$ homeostasis has been widely studied and reported to be crucial in the development 
of neurodegenerative disorders, such as AD, Parkinson's disease, amyotrophic lateral sclerosis or Friedrich Ataxia [4-7].

$\mathrm{Ca}^{2+}$ act as second messengers that transmit external signals to its intracellular targets. $\mathrm{Ca}^{2+}$ signals are generated by a fine regulation between $\mathrm{Ca}^{2+}$ influx and removal, which induces transient fluctuations in the cytosolic $\left[\mathrm{Ca}^{2+}\right]$. The different kinetics, frequency, amplitudes or spatial locations of these transients entails a signalling mechanism able to exert specific impacts in their downstream effectors [8]. Due to its implications in cellular function, cytosolic $\mathrm{Ca}^{2+}$ levels must be therefore tightly regulated, and this becomes essential in excitable cells such as neurons. While a deficient $\mathrm{Ca}^{2+}$ signalling might perturb synaptic transmission [9], sustained elevated levels of cytosolic $\mathrm{Ca}^{2+}$ are detrimental for neurons: $\mathrm{Ca}^{2+}$ overload promotes cell death through different mechanisms, such as necrosis, apoptosis or the more recent ferroptosis, all in which mitochondria play also an essential role $[10,11]$.

In neurons, free cytosolic $\mathrm{Ca}^{2+}$ levels are kept at $\sim 100 \mathrm{nM}$ in resting conditions, while the extracellular concentration reaches the millimolar range, defining a substantial concentration gradient of $10^{4}$. The majority of $\mathrm{Ca}^{2+}$ influx from the extracellular site in neurons occurs through different ion channels located in the plasma membrane, either voltage- or ligand-operated, upon specific stimulation (Figure 1). In the first case, depolarisation of the neurons leads to the opening of different voltage-gated $\mathrm{Ca}^{2+}$ channels (VGCCs) [12], while in the second, the opening of the ionotropic glutamate receptors triggered by the binding of the excitatory neurotransmitter glutamate is the most important example [13]. Regulated $\mathrm{Ca}^{2+}$ release to the cytosol can also occur from intracellular $\mathrm{Ca}^{2+}$ stores such as the highly dynamic endoplasmic reticulum (ER) [14]. In this case, agonist binding to Ryanodine (RyRs) or inositol 1,4,5-triphosphate (IP3) receptors leads to a release of $\mathrm{Ca}^{2+}$ that plays an important role in many neuronal functions [15]. Depletion of the ER induces the activation of the Store-Operated Calcium Entry (SOCE) in order to replenish the organelle. In neurons, STIM proteins located in the ER sense the decrease in $\left[\mathrm{Ca}^{2+}\right]$, accumulate close to the ER-plasma membrane junctions, and interact with the Store-Operated Calcium Channels (SOCCs) in the plasma membrane, allowing the entrance of $\mathrm{Ca}^{2+}$. Orai channels were identified as components of the SOCCs [16], while transient receptor potential channels (TRPC) also play a relevant role [17].

Either way, the duration and spread of the $\mathrm{Ca}^{2+}$ signals is controlled by several clearance mechanisms, which dissipate the massive increase in the cytosolic $\left[\mathrm{Ca}^{2+}\right]$ and restore it to its basal levels to maintain $\mathrm{Ca}^{2+}$ homeostasis. These mechanisms include the efflux of $\mathrm{Ca}^{2+}$ by transporters through the plasma membrane, uptake by organelles such as the ER and the mitochondria and binding to $\mathrm{Ca}^{2+}$-buffering proteins.

The main transporters implicated in the efflux of $\mathrm{Ca}^{2+}$ out of the neurons are the high-affinity, low capacity plasma membrane $\mathrm{Ca}^{2+}$-ATPase (PMCA), which hydrolyses ATP to pump $\mathrm{Ca}^{2+}$ against gradient, and the low affinity, high capacity $\mathrm{Na}^{+} / \mathrm{Ca}^{2+}$ exchanger (NCX), which is abundant in neurons and uses the electrochemical gradient of $\mathrm{Na}^{+}$to extrude $\mathrm{Ca}^{2+}$ [18]. NCX is reversible, and under specific circumstances of $\mathrm{Na}^{+}$and $\mathrm{Ca}^{2+}$ gradient and membrane potential can work in the opposite direction, extruding $\mathrm{Na}^{+}$and letting $\mathrm{Ca}^{2+}$ in [19]. The two main intracellular stores that also collaborate in the uptake of cytosolic $\mathrm{Ca}^{2+}$ are the mitochondria (which will be discussed in detail later) and the ER, which uses the Sarco-Endoplasmic Reticulum $\mathrm{Ca}^{2+}$-ATPase (SERCA) to pump $\mathrm{Ca}^{2+}$ into the ER lumen, at the expense of ATP hydrolysis. Finally, several cytosolic $\mathrm{Ca}^{2+}$-binding proteins also cooperate in the $\mathrm{Ca}^{2+}$ homeostasis by binding and buffering free cytosolic $\mathrm{Ca}^{2+}$. The most important belong to the EF-hand family, and include parvalbumin, calbindin D-28k and calretinin, which are expressed in different areas of the brain [20]. Other members of the family, such as calmodulin, S100 proteins or neuronal $\mathrm{Ca}^{2+}$ sensors (NCS), are also $\mathrm{Ca}^{2+}$-binding proteins that act as $\mathrm{Ca}^{2+}$ sensors which transduce the signal to downstream effectors. The latter involve a complex network of signalling cascades that ultimately have specific cellular effects: $\mathrm{Ca}^{2+}$-calmodulin kinase II, which regulates long-term potentiation, learning and memory; protein kinase A, which modulates neuronal excitability; 
or calpains, a family of proteases that cleave amyloid precursor protein APP or tau protein are just a few examples $[21,22]$.

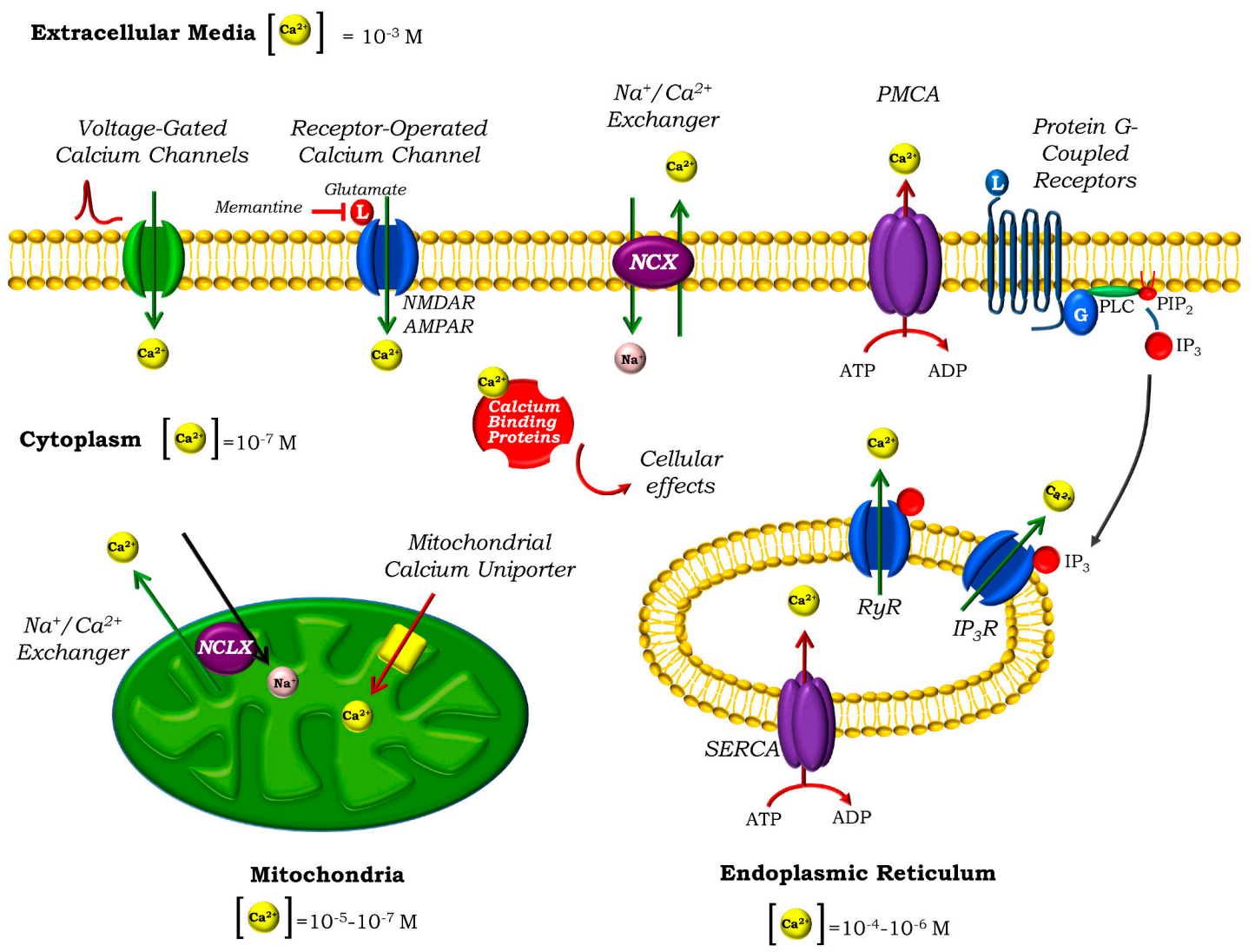

Figure 1. Calcium homeostasis in neurons. $\mathrm{Ca}^{2+}$ signals are shaped by a fine regulation between cytosolic $\mathrm{Ca}^{2+}$ influx and efflux. The main sources for $\mathrm{Ca}^{2+}$ influx are the extracellular media and intracellular stores such as the endoplasmic reticulum (ER). Depolarisation of the neurons leads to the opening of the voltage-gated calcium channels (VGCCs) in the plasma membrane, while ligand binding triggers the opening of the receptor-operated calcium channels (ROCs). AMPA and especially NMDA receptors, both activated by glutamate, are the most important ROCs in the neurons. AD-approved drug memantine is an inhibitor of the NMDARs. $\mathrm{Ca}^{2+}$ can also be released to the cytosol from the ER, after activation of the Ryanodine or inositol 1,4,5-triphosphate $\left(\mathrm{IP}_{3}\right)$ receptors. Binding of a ligand (such as glutamate) to a G-protein-coupled receptor in the plasma membrane (such as specific metabotropic glutamate receptors) activates phospholipase C (PLC), leading to the cleavage of the membrane phospholipid phosphatidylinositol 4,5-bisphosphate $\left(\mathrm{PIP}_{2}\right)$, resulting in the release of the soluble second messenger IP3, that diffuses through the cell and binds its receptor. Cytosolic $\mathrm{Ca}^{2+}$ binds specific $\mathrm{Ca}^{2+}$ binding proteins, which transduce the signal to its final effectors. Excess cytosolic $\mathrm{Ca}^{2+}$ is removed from the cytosol by different mechanisms: (i) efflux through the plasma membrane by the $\mathrm{Na}^{+} / \mathrm{Ca}^{2+}$ exchanger NCX and the plasma membrane $\mathrm{Ca}^{2+}$-ATPase (PMCA), (ii) uptake to the ER by the sarco/endoplasmic reticulum $\mathrm{Ca}^{2+}$-ATPase (SERCA), (iii) uptake to the mitochondria by the mitochondrial $\mathrm{Ca}^{2+}$ uniporter MCU and (iv) buffering by $\mathrm{Ca}^{2+}$ binding proteins. Mitochondrial $\mathrm{Ca}^{2+}$ homeostasis is maintained by the efflux through the mitochondrial $\mathrm{Na}^{+} / \mathrm{Ca}^{2+}$ exchanger NCLX.

\section{Mitochondria and $\mathrm{Ca}^{2+}$ Homeostasis}

Mitochondria play a fundamental role in the rapid buffering and shaping of the cytosolic $\mathrm{Ca}^{2+}$ transients. These are mobile organelles, which can be strategically recruited in close proximity to microdomains with a high cytosolic $\left[\mathrm{Ca}^{2+}\right]$, such as the synapses, acting as highly localised $\mathrm{Ca}^{2+}$ buffers able to shape the local $\mathrm{Ca}^{2+}$ signals and regulate neuronal activity [23]. 
With additional essential roles, such as ROS production or triggering of apoptosis, the best-known mitochondrial function is controlling the bioenergetics of the cell. Substrate oxidation in the Krebs' cycle occurs in the matrix and provides the electron transport chain (ETC) in the inner mitochondrial membrane with $\mathrm{NADH}$ and $\mathrm{FADH}_{2}$. Electrons transfer from these donors to its final acceptor $\mathrm{O}_{2}$ through the ETC is coupled with the translocation of protons to the intermembrane space. This creates an electrochemical gradient whose major component is the membrane potential $(\Delta \Psi \mathrm{m})$, which fuels ATP production in the ATP synthase. Importantly, mitochondrial $\mathrm{Ca}^{2+}$ uptake activates dehydrogenases at the ETC activating mitochondrial respiration and ATP production [24,25].

In addition to its bioenergetics purpose, $\Delta \Psi \mathrm{m}$ is also used by the mitochondria to uptake $\mathrm{Ca}^{2+}$ into their matrix through the high capacity, low-affinity mitochondrial $\mathrm{Ca}^{2+}$ uniporter (MCU) located in the inner membrane. The molecular composition of the uniporter has been recently elucidated, and involves a protein complex consisting on MCU—the pore-forming component-and several regulatory units (MICU1, MICU2, MCUb, MCUR1 and EMRE) (reviewed in [26]). The role of MICU3, highly expressed in the brain, in enhancing MCU Ca ${ }^{2+}$ uptake has been recently described [27]. Current investigations are focused in understanding the regulation of MCU and the specific role of all these proteins in $\mathrm{Ca}^{2+}$ uptake [28,29]. First experiments with MCU knock-out animal models surprisingly revealed that these mice displayed only a mild muscular phenotype [30] and a relatively normal heart function [31]. However, MCU KO in a different genetic background [32] or MICU1 KO appeared to be lethal [33]. Other studies focused in brain function show that silencing of MCU during development induces memory impairment in Drosophila [34], and experiments in brain MCU-KO mitochondria revealed that $\mathrm{MCU}$ deletion did not completely block mitochondrial $\mathrm{Ca}^{2+}$ uptake, suggesting additional uptake pathways [35]. Indeed, it is still a matter of debate if the complex regulation of MCU can result in alternative uptake modes or if other MCU-independent mechanisms coexist and mediate $\mathrm{Ca}^{2+}$ uptake in the mitochondria [36,37].

The mitochondrial $\mathrm{Na}^{+} / \mathrm{Ca}^{2+}$ exchanger NCLX, located in the inner mitochondrial membrane [38], was also molecularly identified not long ago [39] as being responsible for mitochondrial $\mathrm{Ca}^{2+}$ efflux in excitable cells. NCLX is a low affinity, high capacity transporter that uses the electrochemical gradient of $\mathrm{Na}^{+}$to extrude $\mathrm{Ca}^{2+}$ from mitochondria. Like other $\mathrm{Na}^{+} / \mathrm{Ca}^{2+}$ exchangers, it is related to the plasma membrane NCX, but in addition to $\mathrm{Na}^{+}$is able to exchange $\mathrm{Li}^{+}$for $\mathrm{Ca}^{2+}$. Considering that the rate of $\mathrm{Ca}^{2+}$ efflux is much slower than MCU-mediated influx, NCLX appears to mediate the rate limiting step in mitochondrial $\mathrm{Ca}^{2+}$ homeostasis [40]. Indeed, in contrast to MCU, NCLX deletion is associated with more severe phenotypes in vivo: conditional cardiac NCLX deletion in mice leads to myocardial dysfunction and fulminant heart failure [41]. Inhibition of NCLX in Parkinson's disease related mutation PINK1 cells leads to mitochondrial $\mathrm{Ca}^{2+}$ overload and cell death $[42,43]$. Regulation of the exchanger activity can occur via different mechanisms such as $\left[\mathrm{Ca}^{2+}\right]$, via direct and indirect mechanisms like calpain-induced degradation, $\mathrm{pH}, \mathrm{PKC}$ or PKA, as recently reviewed in [44]. In addition, a role for plasma membrane NCX1-3 in mediating mitochondrial $\mathrm{Ca}^{2+}$ efflux in brain cells has also been proposed [45-47].

$\mathrm{Ca}^{2+}$ uptake into the mitochondrial matrix stimulates mitochondrial bioenergetics. Several matrix dehydrogenaseses and metabolite carriers are activated by $\mathrm{Ca}^{2+}$, increasing mitochondrial respiration and ATP production $[48,49]$. This suggests a physiological role for mitochondrial $\mathrm{Ca}^{2+}$ in the adaptation of the cell to the energy demands imposed by $\mathrm{Ca}^{2+}$ signalling. However, as with cytosolic $\left[\mathrm{Ca}^{2+}\right]$, mitochondrial $\mathrm{Ca}^{2+}$ content must be tightly regulated. Mitochondrial $\mathrm{Ca}^{2+}$ overload, especially under conditions of oxidative stress, triggers the opening of the mitochondrial permeability transition pore (mPTP), a high-conductance mitochondrial channel whose composition and structure are still under debate. While firmly closed under physiological conditions, after mPTP opening, the mitochondrial inner membrane becomes unselectively permeable to small solutes, leading to $\Delta \Psi \mathrm{m}$ collapse and eventually mitochondrial swelling and necrotic and apoptotic cell death. mPTP opening has been implicated as the mechanism of cell death in many human diseases, thus representing a major therapeutic target [50]. It should be noted that ROS are one of the most important triggers for MPTP in 
combination with $\mathrm{Ca}^{2+}$ overload [51]. Misfolded proteins, including $\beta$-amyloid and tau, are able to induce ROS production in enzymes (including ETC of mitochondria and NADPH oxidase) or produce free radicals in combination with heavy metals, and trigger mPTP opening [52,53].

\section{Calcium Homeostasis Impairment in AD and Tauopathies}

As mentioned before, $\mathrm{Ca}^{2+}$ homeostasis impairment has been linked to many different diseases, including neurodegenerative conditions.

$\mathrm{AD}$ is the most common neurodegenerative disorder and the principal cause of dementia. It affects millions of people worldwide, with numbers expecting to multiply in the next years, conveying a critical social and medical challenge. Clinically, AD is characterised by progressive memory loss and cognitive and behavioural impairment [54]. Neuronal and synaptic loss in specific areas of the hippocampus and neocortex, together with the presence of extracellular $\beta$-amyloid plaques and intracellular neurofibrillary tangles (NFTs) containing tau aggregates comprise the main neuropathological hallmarks of the disease [55]. Together with them, oxidative stress, mitochondrial dysfunction and altered $\mathrm{Ca}^{2+}$ homeostasis have emerged as important actors and been long studied in the last decades to try to unravel the interplay of all these factors in the pathogenesis of the disease $[4,56,57]$. Although the majority of the cases are sporadic, a small percentage of them are rare familiar cases with an early onset, linked to mutations in the amyloid precursor protein APP gene and presenilins 1 and 2 PSEN1 and PSEN2 genes, components of the $\gamma$-secretase complex involved in the amyloidogenic cleavage of APP that leads to $\beta$-amyloid formation [58]. This evidence suggests a critical role for $\beta$-amyloid in AD pathogenesis. Indeed, the Amyloid cascade hypothesis, formulated in the early 1990s by Hardy and Higgins [59], proposes that the deposition of $\beta$-amyloid is the causative agent of AD pathology, leading to NFTs, neuronal loss and dementia. However, $\beta$-amyloid deposits correlate weakly with neuronal death, while spreading of tau pathology through the brain and the number of NFTs are strongly associated with the progression of AD [60]. Tau is a soluble protein that plays a critical role in the stabilisation of the microtubules, but under pathological circumstances self-aggregates into paired-helical fragments (PHF) whose aggregation finally leads to NFTs. Importantly, abnormal tau hyperphosphorylation impacts its pathogenic role and aggregation capacity and indeed deposited tau is highly phosphorylated. In addition, tau isoform imbalance is sufficient to cause neurodegeneration [61]. Interestingly, mutations in the MAPT gene encoding tau protein are not linked to AD, but to frontotemporal dementia (FTD) and other tauopathies, a term that comprehends a wider range of neurodegenerative disorders in which deposits of tau are found in the brain [1]. FTD is characterised by the progressive neurodegeneration of frontal and temporal lobes of the brain, and comprises different molecular and clinical entities affecting behaviour, function and language of the patients, which are usually younger than those with AD [62,63]. Research in FTD has gained increasing attention in the recent years, but as in $\mathrm{AD}$, there is still a lot to learn to be able to prevent or cure these disorders.

The important role of $\mathrm{Ca}^{2+}$ dysfunction in $\mathrm{AD}$ was first proposed by Khachaturian 25 years ago [64]. Growing body of evidence has been published since then, highlighting the multiple molecular mechanisms that can contribute to the $\mathrm{Ca}^{2+}$ homeostasis impairment in $\mathrm{AD}$. The role of tau, and especially $\beta$-amyloid, has been extensively studied in different animal and cellular models.

\subsection{Cytosolic $\mathrm{Ca}^{2+}$ Disturbances in $\mathrm{AD}$ and Tauopathies}

$\beta$-amyloid was first shown to form $\mathrm{Ca}^{2+}$-permeable pores in artificial membranes [65] that lead to dysregulated $\mathrm{Ca}^{2+}$ entry in the cytoplasm of brain cells [66,67]. Although less studied, we, and others, have shown that tau is also able to form ion channels under specific conditions $[68,69]$. Importantly, structure and aggregation stage determined the ability of both proteins to form pores.

Alteration of the glutamatergic signalling, involved in synaptic plasticity, learning and memory, also plays an important role in the $\mathrm{Ca}^{2+}$ imbalance and synaptic dysfunction in $\mathrm{AD}$ [70,71]. Glutamate is the major excitatory neurotransmitter in the brain and activates a family of metabotropic (G-coupled 
proteins) and ionotropic (ion channels) receptors. Among the latter, AMPA, and especially NMDA receptors, have attracted much attention due to its role in mediating glutamate excitotoxicity. Excitotoxicity is defined as the neuronal death induced by cellular overload of $\mathrm{Ca}^{2+}$ due to excessive stimulation of the glutamate receptors, caused, for example, by an excess of extracellular glutamate. It is involved in the mechanism of cell death in acute (stroke) and chronic neurodegenerative disorders and such has attracted great attention in the pathogenesis of $\mathrm{AD}$ [72]. Research has shown that $\beta$-amyloid oligomers can directly activate NMDA receptors [73], and specifically those containing the NR2B subunit $[74,75]$. Receptors expressing this subunit are preferentially localised in the extrasynaptic area and mediate excitotoxicity [76]. It was proposed that modulating the balance between synaptic NR2A and extrasynaptic NR2B may improve behaviour ability in $\beta$-amyloid treated mice [77]. Tau involvement in excitotoxicity has been also described in AD [78-80] and FTD [81]. For a review of the role of glutamate receptors in $\mathrm{AD}$, see in [82]. Importantly, the non-competitive NMDA receptor antagonist memantine is one of the few drugs approved for use in AD.

The rest of the approved drugs for $\mathrm{AD}$ are cholinesterase inhibitors that aim to prevent acetylcholine degradation. Indeed, the cholinergic pathway has been long implicated in AD pathogenesis, and it was proposed that the loss of cholinergic neurotransmission leads to cognitive impairment [83]. Importantly, tau has been shown to play a role in the loss of cholinergic neurons through interaction with muscarinic receptors [84], and some of the toxic effects of $\beta$-amyloid are mediated by its interaction with nicotinic acetylcholine receptors. Interestingly, acetylcholine and antibodies against acetylcholine receptors protect neurons against $\beta$-amyloid-induced cell death but have no effect on the $\beta$-amyloid-induced $\mathrm{Ca}^{2+}$ deregulation [85].

Tau and $\beta$-amyloid-induced $\mathrm{Ca}^{2+}$ dysfunction through VGCCs have been described in different models of AD and tau-induced FTD [86,87]. We have recently shown that in vitro aggregated tau fibrils with the P301S mutation linked to FTD are able to incorporate into membranes and modify their ionic currents, as seen by BLM experiments [69]. When applied to primary neuronal cultures, this leads to the opening of neuronal VGCCs, inducing characteristic $\mathrm{Ca}^{2+}$ transients in these cells. Increased cytosolic $\left[\mathrm{Ca}^{2+}\right]$ is able to activate NADPH oxidase, enhancing ROS production in neurons and leading to cell death. $\mathrm{Ca}^{2+}$ signals and increased ROS production were observed after the acute application of tau aggregates, suggesting a mechanism by which extracellular tau fibrils can incorporate into the membranes and lead to neuronal dysfunction in the neighbouring neurons [69]. Importantly, we show that tau-induced $\mathrm{Ca}^{2+}$ transients and NADPH-driven ROS production were prevented by nifedipine and verapamil, $\mathrm{Ca}^{2+}$ channels blockers commonly used in clinic for hypertension. Clinical trials with these compounds in patients with dementia show heterogeneous results, with many demonstrating no positive effect for $\mathrm{Ca}^{2+}$ blockers in reducing the rate of cognitive decline in $\mathrm{AD}$ patients [88]. However, the severity of the disease at the beginning of the treatment seems to influence the outcome [89]. Indeed, several studies have shown that hypertense patients on treatment with this group of drugs could have a reduced risk of dementia [90-92], suggesting a potential use of these medications for the prevention of the disease that needs to be further confirmed.

$\mathrm{ER} \mathrm{Ca}^{2+}$ dysregulation also plays a role in AD. Many authors have shown an increased $\mathrm{Ca}^{2+}$ release from the ER both through RyRs $[93,94]$ and IP3Rs $[95,96]$ by different mechanisms. In addition, impairment of the STIM-mediated SOCE has been described in familiar models of the disease $[97,98]$ and recent studies point at the role of tau in ER stress through TRPC and SOCE upregulation [99].

$\mathrm{Ca}^{2+}$ efflux through the plasma membrane by PMCA can be inhibited by $\beta$-amyloid and tau, as shown by Mata et al., whose findings are summarised in their review [100]. Both proteins appear to bind the transporter, with tau inhibitory effect occurring in the nanomolar range. In addition, the possible oxidation of PMCA induced by $\beta$-amyloid and tau might lead to a decrease in the ATPase activity [101]. $\beta$-amyloid is also able to interact with the plasma membrane NCX and reduce its activity [102]. Differing results have been published regarding the protein levels of NCX isotypes in the different areas of brains of patients [103]. However, studies in AD brains and neuronal cultures pointed the specific altered cleavage of NCX3 (and not NCX1) mediated by the $\mathrm{Ca}^{2+}$-dependent protease 
calpain [104]. Interestingly, this feature appeared only in AD brains and not in brains from tauopathies like FTD, suggesting a specific role for $\beta$-amyloid and not tau. In addition, both NCX and PMCA can be downregulated in response to oxidative stress [105].

Calpain overactivation has been consistently reported in AD and tauopathy brains [106], and $\beta$-amyloid [107] and tauopathy models [108,109]. Other $\mathrm{Ca}^{2+}$-dependent molecules, such as calmodulin and its binding proteins have a prominent role in $\mathrm{AD} \mathrm{[110]} \mathrm{and} \mathrm{have} \mathrm{been} \mathrm{suggested} \mathrm{as} \mathrm{potential}$ biomarkers of the disease [111].

\subsection{Mitochondrial $\mathrm{Ca}^{2+}$ Disturbances in $\mathrm{AD}$ and Tauopathies}

Neurons, as excitable cells, are continuously firing action potentials and employing a vast $\mathrm{Ca}^{2+}$ signalling that comes at the expense of an increased metabolic demand to maintain $\mathrm{Ca}^{2+}$ homeostasis (for example through $\mathrm{Ca}^{2+}$-ATPases) and re-establish electrochemical gradients. In this context, mitochondria play a fundamental role in maintaining the metabolic needs. This could represent a challenge in neurodegenerative disorders, in which mitochondrial dysfunction has been extensively described together with oxidative stress and $\mathrm{Ca}^{2+}$ impairment, all of which are implicated in the pathogenesis of the disease $[53,57,112]$.

In addition, mitochondria themselves are direct sites of action of $\beta$-amyloid and tau. $\beta$-amyloid has been shown to be imported via TOM [113] and directly produced in this organelle [114], while a fraction of intracellular tau has been found to locate within the inner mitochondrial space [115]. Indeed, mitochondrial accumulation of tau in synaptosomes from AD brains appeared to correlate with synaptic loss [116].

Tau and beta-amyloid dysfunction have been widely linked to altered cytosolic $\mathrm{Ca}^{2+}$ homeostasis through the different mechanisms explained before. These scenarios compromise mitochondria in two ways: challenging mitochondrial $\mathrm{Ca}^{2+}$ buffering capacity, which might become overloaded, and, in addition, the cellular bioenergetics of cells in which mitochondrial function could be already impaired. Mitochondrial $\mathrm{Ca}^{2+}$ uptake by MCU is driven by the $\Delta \Psi \mathrm{m}$, and therefore mitochondrial depolarisation might compromise the uptake of $\mathrm{Ca}^{2+}$ and its physiological role in bioenergetics, and in addition expose the cytosol to higher $\left[\mathrm{Ca}^{2+}\right]$. On the other hand, mitochondrial depolarisation and bioenergetics dysfunction can be triggered by $\mathrm{Ca}^{2+}$ and prevented by the inhibition of mitochondrial $\mathrm{Ca}^{2+}$ uptake as previously shown in works by Abramov and Duchen [117-119].

Several reports highlight the role of the mitochondrial $\mathrm{Ca}^{2+}$ uptake in neuronal death induced by glutamate excitotoxicity $[120,121]$. Qiu et al. showed that MCU overexpression exacerbated excitotoxic cell death, while MCU silencing prevented NMDA-induced mitochondrial $\mathrm{Ca}^{2+}$ uptake protecting neurons from excitotoxic cell death [122]. Our group has recently described the protective role of a novel compound, TG-2112x, which is able to partially inhibit mitochondrial $\mathrm{Ca}^{2+}$ uptake without affecting $\Delta \Psi \mathrm{m}$ or bioenergetics, and protects neurons against glutamate excitotoxicity [123]. These results from Angelova et al. suggest this compound as a new therapeutic opportunity in diseases such as $\mathrm{AD}$ in which excitotoxicity play a detrimental role.

Other authors have proposed that the induction of a mild mitochondrial uncoupling with different agents such as non-steroidal anti-inflammatory drugs (NSAIDs) could also reduce mitochondrial $\mathrm{Ca}^{2+}$ uptake and prevent overload induced by $\beta$-amyloid, protecting neurons against cell death in AD [124]. Results from trials have been however conflicting, probably due to the narrow effective dose window for this strategy, as high doses might lead to opposite effects and collapse the $\Delta \Psi \mathrm{m}$ [125].

Recent in vivo imaging by Calvo-Rodriguez et al. in the APP/PS1 transgenic mouse model of AD has shown $\beta$-amyloid dependent mitochondrial $\mathrm{Ca}^{2+}$ overload in a subset of neurons in the brain of these mice, which preceded neuronal death and could be prevented by MCU inhibition [126]. Interestingly, neuronal death did not occur in neighbour cells with lower mitochondrial $\mathrm{Ca}^{2+}$ levels highlighting one more time the deleterious effect of mitochondrial $\mathrm{Ca}^{2+}$ overload. This work also evaluated available microarray and RNA-Sequencing datasheets to analyse the expression of mitochondrial $\mathrm{Ca}^{2+}$-related genes in patients with $\mathrm{AD}$ and found that all the genes involved in mitochondrial uptake 
were downregulated, while Slc8b1 gene encoding NCLX was significantly upregulated, suggesting a possible compensatory response to prevent mitochondrial $\mathrm{Ca}^{2+}$ overload [126]. However, other reports show contradictory results [127].

The mitochondria-associated ER membranes are subcompartments of the ER connected physically and biochemically to the mitochondria allowing the communication between both organelles and the transfer of $\mathrm{Ca}^{2+}$ from ER to mitochondria [128]. Many relevant functions for the pathogenesis of AD such as $\beta$-amyloid production appear to occur in these regions [129] and a higher degree of apposition between ER and mitochondria has been found in AD cells, brains and mouse models [130,131]. As seen in preselinin 2 (PS2) cellular and animal models of AD, the increased ER-mitochondria interactions enhance $\mathrm{Ca}^{2+}$ transfer, which might contribute to mitochondrial $\mathrm{Ca}^{2+}$ overload [132,133]. Some authors have shown that presenilins are able to form cation-permeable pores responsible for passive $\mathrm{Ca}^{2+}$ leak from the ER [134], thus contributing to the pathogenesis of the disease, although this hypothesis is under debate, with other authors showing opposite results [135].

mPTP opening induced by mitochondrial $\mathrm{Ca}^{2+}$ overload is one of the mechanisms of $\beta$-amyloidand tau-induced mitochondrial dysfunction and cell death $[6,8,136-138]$. $\beta$-amyloid is able to interact with a key component of the pore, cyclophilin $\mathrm{D}$, and potentiate mitochondrial dysfunction and $\mathrm{mPTP}$ formation [139]. Reduction in cyclophilin D expression, on the other hand, protects neurons and improves learning and memory in mouse models of $\mathrm{AD}$ [139]. In addition, treatment with the classical blocker of MPTP, cyclosporine A, or removal of polyphosphate, thought to be a component of the pore, are able to prevent $\beta$-amyloid-induced $\mathrm{mPTP}$ opening and cell death $[119,137]$.

Impairment of mitochondrial $\mathrm{Ca}^{2+}$ efflux has not been explored in the pathogenesis of AD until very recently. Jadiya et al. have shown in different mouse and animal models of the disease that AD progression is associated with the loss of NCLX expression and functionality [127]. Importantly, genetic rescue of NCLX expression in neurons completely restored the cognitive decline and the cellular pathology in the $\mathrm{AD}$ mice.

Recent work from our group has shown for the first time the tau-induced altered mitochondrial $\mathrm{Ca}^{2+}$ efflux through NCLX in neurons [138]. In this study, we show that K18 tau, a fragment of the protein comprising the four repeat (4R) region of the protein, led to cytosolic $\mathrm{Ca}^{2+}$ oscillations in primary neurons after $24 \mathrm{~h}$ incubation. These oscillations were followed by mitochondrial $\mathrm{Ca}^{2+}$ uptake, and induced a gradual increase in basal cytosolic and mitochondrial $\mathrm{Ca}^{2+}$, suggesting an impaired $\mathrm{Ca}^{2+}$ handling induced by tau [138]. Stimulation of a physiological $\mathrm{Ca}^{2+}$ signal with glutamate (in neurons) or ATP (in astrocytes) incubated with tau further evidenced a slower cytosolic and mitochondrial $\mathrm{Ca}^{2+}$ efflux in both cell types. Experiments in permeabilised cells confirmed that the impairment was mediated by NCLX, as showed by the altered $\mathrm{Na}^{+}$and $\mathrm{Ca}^{2+}$ currents. More importantly, tau-induced NCLX impairment led to a faster mitochondrial depolarisation when exposing the neurons to (pathological) repetitive $\mathrm{Ca}^{2+}$ stimulations, suggesting an increased vulnerability to $\mathrm{Ca}^{2+}$-induced cell death [138]. iPSC-derived neurons from patients carrying the FTD-related 10+16 mutation in MAPT were also more vulnerable to physiological and pathological $\mathrm{Ca}^{2+}$ stimulation, and presented an increased susceptibility to mPTP opening [138].

10+16 MAPT mutation also impairs neuronal excitability [140] and bioenergetics of iPSC-derived neurons [141]. In contrast to other neurodegeneration models [142,143], 10+16 MAPT neurons display an increased mitochondrial membrane potential [141]. As a result, mitochondrial ROS production in the neurons is enhanced, leading to oxidative stress and neuronal death, all of which are prevented treating the cells with mitochondrial antioxidants.Oxidative stress, in combination with mitochondrial $\mathrm{Ca}^{2+}$ overload, are the triggers for MPTP opening. Preliminary data shows that mitochondrial antioxidants are able to protect the 10+16 neurons and reduce their susceptibility to MPTP opening (Figure 2). Confirming previous results [138], cellular $\mathrm{Ca}^{2+}$ overload induced by the ionophore ferutinin triggered mPTP opening and led to apoptosis in iPSC-neurons, which occurred significantly earlier in the FTD patients than in controls (Figure 2). Treatment with the mitochondrial antioxidant MitoTEMPO (MT, 1 $\mathrm{h}, 100 \mathrm{nM}$ ) significantly delayed the mPTP opening in the patients' neurons to times similar to control, 
thus counteracting their increased vulnerability. This, together with previous results [141], highlights the potential role of mitochondrial antioxidants in the prevention of neuronal death through different mechanisms that might include averting mitochondrial $\mathrm{Ca}^{2+}$ overload. Further investigations will be needed to prove this point and understand if this effect is merely due to the reduction of the already elevated mitochondrial ROS, or if mito ROS overproduction induced by tau might influence other aspects of cytosolic or mitochondrial $\mathrm{Ca}^{2+}$ homeostasis trough different mechanisms such as redox regulation. These results highlight the close interconnection between impaired bioenergetics, oxidative stress and $\mathrm{Ca}^{2+}$ signalling in tau pathology.

A.

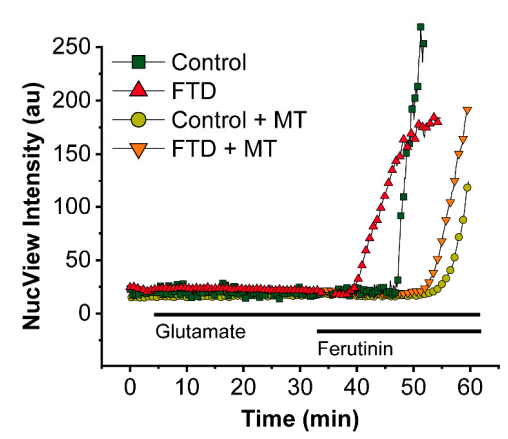

B.

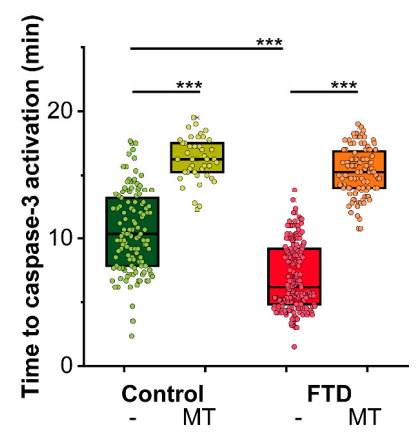

Figure 2. Mitochondrial antioxidants reduce FTD neurons vulnerability to mPTP opening. (A) Representative traces depict NucView intensity in iPSC-derived neurons from controls or FTD-related mutation 10+16 in MAPT treated or not with MitoTEMPO (MT) $100 \mathrm{nM}$ and exposed to $50 \mu \mathrm{m}$ glutamate or the electrogenic $\mathrm{Ca}^{2+}$ ionophore ferutinin $[144,145]$. Sudden increase in NucView fluorescence indicates caspase- 3 activation. (B) Time to caspase-3 activation after $\mathrm{Ca}^{2+}$ overload with ferutinin. Box represents median and 25, 75 percentiles. $n=126$ neurons analysed in control, FTD $n=199$, control + MT, $n=43$, FTD + MT, $n=104$. ${ }^{* * *} p<0.001$, Mann-Whitney test. Method: iPSC-derived neurons were loaded with the non-fluorescent caspase-3 substrate NucView 488 for $15 \mathrm{~min}$. NucView is cleaved upon caspase- 3 activation inducing a sudden increase in green fluorescence. Images were taken on a Zeiss 710 LSM confocal microscope with an integrated META detection system.

\section{Conclusions}

$\mathrm{Ca}^{2+}$, and especially mitochondrial $\mathrm{Ca}^{2+}$ homeostasis, plays a key role in neurodegenerative disorders including AD and other tauopathies like FTD. As detailed in the present review, both $\beta$-amyloid and tau protein induce cytosolic and mitochondrial $\mathrm{Ca}^{2+}$ deregulation through different direct and indirect pathways that ultimately lead to neuronal dysfuntion and cell death. Importantly, isoform type, length, or aggregation stage, among other characteristics of these proteins have been shown to influence the pathogenic mechanism. Mitochondrial $\mathrm{Ca}^{2+}$ overload appears as a downstream key event in the process of neurodegeneration, and recent studies point at a direct role of these proteins in the impairment of mitochondrial $\mathrm{Ca}^{2+}$ influx ( $\beta$-amyloid) and efflux ( $\beta$-amyloid and tau). Specific targeting of the mechanisms leading to $\mathrm{Ca}^{2+}$ impairment, and especially mitochondria-targeted therapies emerge as potential treatments for these disorders.

Funding: This research received no external funding.

Acknowledgments: We would like to thank Dr. Selina Wray, who generated the iPSC lines from patients used in this manuscript.

Conflicts of Interest: The authors declare no conflict of interest. 


\section{References}

1. Spillantini, M.G.; Goedert, M. Tau pathology and neurodegeneration. Lancet Neurol. 2013, 12, $609-622$. [CrossRef]

2. Horigane, S.-I.; Ozawa, Y.; Yamada, H.; Takemoto-Kimura, S. Calcium signalling: A key regulator of neuronal migration. J. Biochem. 2019, 165, 401-409. [CrossRef]

3. Wojda, U.; Salinska, E.; Kuźnicki, J. Calcium ions in neuronal degeneration. Iubmb Life 2008, 60, 575-590. [CrossRef]

4. Alzheimer's Association Calcium Hypothesis Workgroup; Khachaturian, Z.S. Calcium Hypothesis of Alzheimer's disease and brain aging: A framework for integrating new evidence into a comprehensive theory of pathogenesis. Alzheimer's Dement. 2017, 13, 178-182. [CrossRef]

5. Britti, E.; Delaspre, F.; Tamarit, J.; Ros, J.; Ros, J. Mitochondrial calcium signalling and neurodegenerative diseases. Neuronal Signal. 2018, 2, NS20180061. [CrossRef]

6. Abeti, R.; Abramov, A.Y. Mitochondrial Ca2+ in neurodegenerative disorders. Pharm. Res. 2015, 99, $377-381$. [CrossRef]

7. Ludtmann, M.H.R.; Abramov, A.Y. Mitochondrial calcium imbalance in Parkinson's disease. Neurosci. Lett. 2018, 663, 86-90. [CrossRef]

8. Semyanov, A.V. Spatiotemporal pattern of calcium activity in astrocytic network. Cell Calcium 2019, 78, 15-25. [CrossRef]

9. Shankar, G.M.; Bloodgood, B.L.; Townsend, M.; Walsh, D.M.; Selkoe, D.J.; Sabatini, B.L. Natural Oligomers of the Alzheimer Amyloid- Protein Induce Reversible Synapse Loss by Modulating an NMDA-Type Glutamate Receptor-Dependent Signaling Pathway. J. Neurosci. 2007, 27, 2866-2875. [CrossRef]

10. Orrenius, S.; Gogvadze, V.; Zhivotovsky, B. Calcium and mitochondria in the regulation of cell death. Biochem. Biophys. Res. Commun. 2015, 460, 72-81. [CrossRef]

11. Angelova, P.R.; Choi, M.L.; Berezhnov, A.V.; Horrocks, M.H.; Hughes, C.D.; De, S.; Rodrigues, M.; Yapom, R.; Little, D.; Dolt, K.S.; et al. Alpha synuclein aggregation drives ferroptosis: An interplay of iron, calcium and lipid peroxidation. Cell Death Differ. 2020, 27, 2781-2796. [CrossRef] [PubMed]

12. Simms, B.A.; Zamponi, G.W. Neuronal Voltage-Gated Calcium Channels: Structure, Function, and Dysfunction. Neuron 2014, 82, 24-45. [CrossRef] [PubMed]

13. Reiner, A.; Levitz, J. Glutamatergic Signaling in the Central Nervous System: Ionotropic and Metabotropic Receptors in Concert. Neuron 2018, 98, 1080-1098. [CrossRef] [PubMed]

14. Verkhratsky, A. Endoplasmic reticulum calcium signaling in nerve cells. Boil. Res. 2004, 37, $693-699$. [CrossRef] [PubMed]

15. Karagas, N.E.; Venkatachalam, K. Roles for the Endoplasmic Reticulum in Regulation of Neuronal Calcium Homeostasis. Cells 2019, 8, 1232. [CrossRef]

16. Prakriya, M.; Feske, S.; Gwack, Y.; Srikanth, S.; Rao, A.; Hogan, P.G. Orai1 is an essential pore subunit of the CRAC channel. Nat. 2006, 443, 230-233. [CrossRef]

17. López, J.J.; Jardin, I.; Sánchez-Collado, J.; Salido, G.M.; Smani, T.; Rosado, J.A. TRPC Channels in the SOCE Scenario. Cells 2020, 9, 126. [CrossRef]

18. Brini, M.; Carafoli, E. The Plasma Membrane Ca2+ ATPase and the Plasma Membrane Sodium Calcium Exchanger Cooperate in the Regulation of Cell Calcium. Cold Spring Harb. Perspect. Boil. 2010, 3, a004168. [CrossRef]

19. Roome, C.J.; Power, E.M.; Empson, R. Transient reversal of the sodium/calcium exchanger boosts presynaptic calcium and synaptic transmission at a cerebellar synapse. J. Neurophysiol. 2013, 109, 1669-1680. [CrossRef]

20. Schwaller, B. Cytosolic Ca2+ Buffers. Cold Spring Harb. Perspect. Boil. 2010, 2, a004051. [CrossRef]

21. Burgoyne, R.D. Neuronal calcium sensor proteins: Generating diversity in neuronal Ca2+ signalling. Nat. Rev. Neurosci. 2007, 8, 182-193. [CrossRef]

22. Sharma, R.K.; Parameswaran, S. Calmodulin-binding proteins: A journey of 40 years. Cell Calcium 2018, 75, 89-100. [CrossRef] [PubMed]

23. Rizzuto, R.; De Stefani, D.; Raffaello, A.; Mammucari, C. Mitochondria as sensors and regulators of calcium signalling. Nat. Rev. Mol. Cell Boil. 2012, 13, 566-578. [CrossRef] [PubMed]

24. Abramov, A.Y.; Angelova, P.R. Cellular mechanisms of complex I-associated pathology. Biochem. Soc. Trans. 2019, 47, 1963-1969. [CrossRef] 
25. McCormack, J.G.; Denton, R.M. The role of intramitochondrial Ca2+ in the regulation of oxidative phosphorylation in mammalian tissues. Biochem. Soc. Trans. 1993, 21, 793-799. [CrossRef]

26. Kamer, K.J.; Mootha, V.K. The molecular era of the mitochondrial calcium uniporter. Nat. Rev. Mol. Cell Boil. 2015, 16, 545-553. [CrossRef] [PubMed]

27. Patron, M.; Granatiero, V.; Espino, J.; Rizzuto, R.; De Stefani, D. MICU3 is a tissue-specific enhancer of mitochondrial calcium uptake. Cell Death Differ. 2018, 26, 179-195. [CrossRef]

28. Fan, M.; Zhang, J.; Tsai, C.-W.; Orlando, B.J.; Rodriguez, M.; Xu, Y.; Liao, M.; Tsai, M.-F.; Feng, L. Structure and mechanism of the mitochondrial Ca2+ uniporter holocomplex. Nature 2020, 582, 129-133. [CrossRef]

29. Wu, W.; Shen, Q.; Zhang, R.; Qiu, Z.; Wang, Y.; Zheng, J.; Jia, Z. The structure of the MICU 1- MICU 2 complex unveils the regulation of the mitochondrial calcium uniporter. Embo J. 2020, 10. [CrossRef]

30. Pan, X.; Liu, J.; Nguyen, T.; Liu, C.; Sun, J.; Teng, Y.; Fergusson, M.M.; Rovira, I.I.; Allen, M.; Springer, D.A.; et al. The physiological role of mitochondrial calcium revealed by mice lacking the mitochondrial calcium uniporter. Nature 2013, 15, 1464-1472. [CrossRef]

31. Holmstrom, K.; Pan, X.; Liu, J.C.; Menazza, S.; Liu, J.; Nguyen, T.T.; Pan, H.; Parks, R.J.; Anderson, S.A.; Noguchi, A.; et al. Assessment of cardiac function in mice lacking the mitochondrial calcium uniporter. J. Mol. Cell. Cardiol. 2015, 85, 178-182. [CrossRef] [PubMed]

32. Murphy, E.; Pan, X.; Nguyen, T.; Liu, J.; Holmstrom, K.; Finkel, T. Unresolved questions from the analysis of mice lacking MCU expression. Biochem. Biophys. Res. Commun. 2014, 449, 384-385. [CrossRef] [PubMed]

33. Antony, A.N.; Paillard, M.; Moffat, C.; Juskeviciute, E.; Correnti, J.; Bolon, B.; Rubin, E.; Csordás, G.; Seifert, E.L.; Hoek, J.B.; et al. MICU1 regulation of mitochondrial Ca2+ uptake dictates survival and tissue regeneration. Nat. Commun. 2016, 7, 10955. [CrossRef] [PubMed]

34. Drago, I.; Davis, R.L. Inhibiting the Mitochondrial Calcium Uniporter during Development Impairs Memory in Adult Drosophila. Cell Rep. 2016, 16, 2763-2776. [CrossRef]

35. Hamilton, J.; Brustovetsky, T.; Rysted, J.E.; Lin, Z.; Usachev, Y.M.; Brustovetsky, N. Deletion of mitochondrial calcium uniporter incompletely inhibits calcium uptake and induction of the permeability transition pore in brain mitochondria. J. Boil. Chem. 2018, 293, 15652-15663. [CrossRef]

36. Elustondo, P.A.; Nichols, M.; Robertson, G.S.; Pavlov, E.V. Mitochondrial Ca2+ uptake pathways. J. Bioenerg. Biomembr. 2016, 49, 113-119. [CrossRef]

37. De Stefani, D.; Patron, M.; Rizzuto, R. Structure and function of the mitochondrial calcium uniporter complex. Biochim. Et Biophys. Acta (Bba) 2015, 1853, 2006-2011. [CrossRef]

38. Carafoli, E.; Tiozzo, R.; Lugli, G.; Crovetti, F.; Kratzing, C. The release of calcium from heart mitochondria by sodium. J. Mol. Cell. Cardiol. 1974, 6, 361-371. [CrossRef]

39. Palty, R.; Silverman, W.F.; Hershfinkel, M.; Caporale, T.; Sensi, S.L.; Parnis, J.; Nolte, C.; Fishman, D.; Shoshan-Barmatz, V.; Herrmann, S.; et al. NCLX is an essential component of mitochondrial Na+/Ca2+ exchange. Proc. Natl. Acad. Sci. USA 2009, 107, 436-441. [CrossRef]

40. Drago, I.; De Stefani, D.; Rizzuto, R.; Pozzan, T. Mitochondrial Ca2+ uptake contributes to buffering cytoplasmic Ca2+ peaks in cardiomyocytes. Proc. Natl. Acad. Sci. USA 2012, 109, 12986-12991. [CrossRef]

41. Luongo, T.S.; Lambert, J.; Gross, P.; Nwokedi, M.; Lombardi, A.A.; Shanmughapriya, S.; Carpenter, A.C.; Kolmetzky, D.; Gao, E.; Van Berlo, J.H.; et al. The mitochondrial Na+/Ca2+ exchanger is essential for Ca2+ homeostasis and viability. Nature 2017, 545, 93-97. [CrossRef] [PubMed]

42. Gandhi, S.; Wood-Kaczmar, A.; Yao, Z.; Plun-Favreau, H.; Deas, E.; Klupsch, K.; Downward, J.; Latchman, D.S.; Tabrizi, S.J.; Wood, N.W.; et al. PINK1-Associated Parkinson's Disease Is Caused by Neuronal Vulnerability to Calcium-Induced Cell Death. Mol. Cell 2009, 33, 627-638. [CrossRef]

43. Kostić, M.; Ludtmann, M.H.R.; Bading, H.; Hershfinkel, M.; Steer, E.; Chu, C.T.; Abramov, A.Y.; Sekler, I. PKA Phosphorylation of NCLX Reverses Mitochondrial Calcium Overload and Depolarization, Promoting Survival of PINK1-Deficient Dopaminergic Neurons. Cell Rep. 2015, 13, 376-386. [CrossRef] [PubMed]

44. Kostic, M.; Sekler, I. Functional properties and mode of regulation of the mitochondrial $\mathrm{Na}+/ \mathrm{Ca}+$ exchanger, NCLX. Semin. Cell Dev. Boil. 2019, 94, 59-65. [CrossRef] [PubMed]

45. Wood-Kaczmar, A.; Deas, E.; Wood, N.W.; Abramov, A.Y. The Role of the Mitochondrial NCX in the Mechanism of Neurodegeneration in Parkinson's Disease. Neurotransm. Interact. Cogn. Funct. 2012, 961, 241-249. [CrossRef] 
46. Gobbi, P.; Castaldo, P.; Minelli, A.; Salucci, S.; Magi, S.; Corcione, E.; Amoroso, S. Mitochondrial localization of $\mathrm{Na}+/ \mathrm{Ca} 2+$ exchangers NCX1-3 in neurons and astrocytes of adult rat brain in situ. Pharm. Res. 2007, 56, 556-565. [CrossRef]

47. Sisalli, M.J.; Secondo, A.; Esposito, A.; Valsecchi, V.; Savoia, C.; Di Renzo, G.F.; Annunziato, L.; Scorziello, A. Endoplasmic reticulum refilling and mitochondrial calcium extrusion promoted in neurons by NCX1 and NCX3 in ischemic preconditioning are determinant for neuroprotection. Cell Death Differ. 2014, 21, 1142-1149. [CrossRef]

48. Glancy, B.; Balaban, R.S. Role of Mitochondrial Ca2+in the Regulation of Cellular Energetics. Biochemistry 2012, 51, 2959-2973. [CrossRef]

49. Llorente-Folch, I.; Rueda, C.B.; Amigo, I.; Del Arco, A.; Saheki, T.; Pardo, B.; Satrústegui, J. Calcium-Regulation of Mitochondrial Respiration Maintains ATP Homeostasis and Requires ARALAR/AGC1-Malate Aspartate Shuttle in Intact Cortical Neurons. J. Neurosci. 2013, 33, 13957-13971. [CrossRef]

50. Briston, T.; Selwood, D.; Szabadkai, G.; Duchen, M.R. Mitochondrial Permeability Transition: A Molecular Lesion with Multiple Drug Targets. Trends Pharm. Sci. 2019, 40, 50-70. [CrossRef]

51. Angelova, P.R.; Abramov, A.Y. Role of mitochondrial ROS in the brain: From physiology to neurodegeneration. FEBS Lett. 2018, 592, 692-702. [CrossRef] [PubMed]

52. Abramov, A.Y.; Potapova, E.; Dremin, V.; Dunaev, A.V. Interaction of Oxidative Stress and Misfolded Proteins in the Mechanism of Neurodegeneration. Life 2020, 10, 101. [CrossRef] [PubMed]

53. Angelova, P.R.; Esteras, N.; Abramov, A.Y. Mitochondria and lipid peroxidation in the mechanism of neurodegeneration: Finding ways for prevention. Med. Res. Rev. 2020. [CrossRef]

54. McKhann, G.M.; Knopman, D.S.; Chertkow, H.; Hyman, B.T.; Jack, C.R.; Kawas, C.H.; Klunk, W.E.; Koroshetz, W.J.; Manly, J.J.; Mayeux, R.; et al. The diagnosis of dementia due to Alzheimer's disease: Recommendations from the National Institute on Aging-Alzheimer's Association workgroups on diagnostic guidelines for Alzheimer's disease. Alzheimer's Dement. 2011, 7, 263-269. [CrossRef] [PubMed]

55. Ballard, C.; Gauthier, S.; Corbett, A.; Brayne, C.; Aarsland, D.; Jones, E. Alzheimer's disease. Lancet 2011, 377, 1019-1031. [CrossRef]

56. Popugaeva, E.; Pchitskaya, E.; Bezprozvanny, I. Dysregulation of neuronal calcium homeostasis in Alzheimer's disease - A therapeutic opportunity? Biochem. Biophys. Res. Commun. 2016, 483, 998-1004. [CrossRef]

57. Angelova, P.R.; Abramov, A.Y. Alpha-synuclein and beta-amyloid - different targets, same players: Calcium, free radicals and mitochondria in the mechanism of neurodegeneration. Biochem. Biophys. Res. Commun. 2017, 483, 1110-1115. [CrossRef]

58. Hardy, J. Amyloid, the presenilins and Alzheimer's disease. Trends Neurosci. 1997, 20, 154-159. [CrossRef]

59. Hardy, J.; Higgins, G.; Mayford, M.; Barzilai, A.; Keller, F.; Schacher, S.; Kandel, E. Alzheimer's disease: The amyloid cascade hypothesis. Science 1992, 256, 184-185. [CrossRef]

60. Arriagada, P.V.; Growdon, J.H.; Hedley-Whyte, E.T.; Hyman, B.T. Neurofibrillary tangles but not senile plaques parallel duration and severity of Alzheimer's disease. Neurology 1992, 42, 631. [CrossRef]

61. Rösler, T.W.; Marvian, A.T.; Brendel, M.; Nykänen, N.-P.; Höllerhage, M.; Schwarz, S.C.; Hopfner, F.; Koeglsperger, T.; Respondek, G.; Schweyer, K.; et al. Four-repeat tauopathies. Prog. Neurobiol. 2019, 180, 101644. [CrossRef] [PubMed]

62. Bang, J.; Spina, S.; Miller, B.L. Frontotemporal dementia. Lancet 2015, 386, 1672-1682. [CrossRef]

63. MacKenzie, I.R.A.; Neumann, M. Molecular neuropathology of frontotemporal dementia: Insights into disease mechanisms from postmortem studies. J. Neurochem. 2016, 138, 54-70. [CrossRef] [PubMed]

64. Khachaturian, Z.S. Calcium Hypothesis of Alzheimer's Disease and Brain Aginga. Ann. N. Y. Acad. Sci. 2006, 747, 1-11. [CrossRef]

65. Arispe, N.; Pollard, H.B.; Rojas, E. Giant multilevel cation channels formed by Alzheimer disease amyloid beta-protein [A beta P-(1-40)] in bilayer membranes. Proc. Natl. Acad. Sci. USA 1993, 90, 10573-10577. [CrossRef] [PubMed]

66. Abramov, A.Y.; Canevari, L.; Duchen, M.R. Changes in Intracellular Calcium and Glutathione in Astrocytes as the Primary Mechanism of Amyloid Neurotoxicity. J. Neurosci. 2003, 23, 5088-5095. [CrossRef]

67. Abramov, A.Y.; Canevari, L.; Duchen, M.R. Calcium signals induced by amyloid $\beta$ peptide and their consequences in neurons and astrocytes in culture. Biochim. Biophys. Acta (BBA) 2004, 1742, 81-87. [CrossRef]

68. Patel, N.; Ramachandran, S.; Azimov, R.; Kagan, B.L.; Lal, R. Ion Channel Formation by Tau Protein: Implications for Alzheimer's Disease and Tauopathies. Biochemistry 2015, 54, 7320-7325. [CrossRef] 
69. Esteras, N.; Kundel, F.; Amodeo, G.F.; Pavlov, E.V.; Klenerman, D.; Abramov, A.Y. Insoluble tau aggregates induce neuronal death through modification of membrane ion conductance, activation of voltage-gated calcium channels and NADPH oxidase. FEBS J. 2020. [CrossRef]

70. Nalbantoglu, J.; Tirado-Santiago, G.; Lahsaïni, A.; Poirier, J.; Gonçalves, O.; Verge, G.; Momoli, F.; Welner, S.A.; Massicotte, G.; Julien, J.-P.; et al. Impaired learning and LTP in mice expressing the carboxy terminus of the Alzheimer amyloid precursor protein. Nature 1997, 387, 500-505. [CrossRef]

71. Snyder, E.M.; Nong, Y.; Almeida, C.G.; Paul, S.; Moran, T.; Choi, E.Y.; Nairn, A.C.; Salter, M.W.; Lombroso, P.J.; Gouras, G.K.; et al. Regulation of NMDA receptor trafficking by amyloid- $\beta$. Nat. Neurosci. 2005, 8, 1051-1058. [CrossRef] [PubMed]

72. Lewerenz, J.; Maher, P. Chronic Glutamate Toxicity in Neurodegenerative Diseases-What is the Evidence? Front. Mol. Neurosci. 2015, 9, 469. [CrossRef]

73. Texidó, L.; Martín-Satué, M.; Alberdi, E.; Solsona, C.; Matute, C. Amyloid $\beta$ peptide oligomers directly activate NMDA receptors. Cell Calcium 2011, 49, 184-190. [CrossRef]

74. Ferreira, I.L.; Bajouco, L.; Mota, S.; Auberson, Y.; Oliveira, C.R.; Rego, A.C. Amyloid beta peptide 1-42 disturbs intracellular calcium homeostasis through activation of GluN2B-containing N-methyl-d-aspartate receptors in cortical cultures. Cell Calcium 2012, 51, 95-106. [CrossRef]

75. Rammes, G.; Seeser, F.; Mattusch, K.; Zhu, K.; Haas, L.; Kummer, M.; Heneka, M.; Herms, J.; Parsons, C.G. The NMDA receptor antagonist Radiprodil reverses the synaptotoxic effects of different amyloid-beta $(\mathrm{A} \beta)$ species on long-term potentiation (LTP). Neuropharmacology 2018, 140, 184-192. [CrossRef] [PubMed]

76. Liu, Y.; Wong, T.P.; Aarts, M.M.; Rooyakkers, A.; Liu, L.; Lai, T.W.; Wu, D.C.; Lu, J.; Tymianski, M.; Craig, A.M.; et al. NMDA Receptor Subunits Have Differential Roles in Mediating Excitotoxic Neuronal Death Both In Vitro and In Vivo. J. Neurosci. 2007, 27, 2846-2857. [CrossRef] [PubMed]

77. Huang, Y.; Shen, W.; Su, J.; Cheng, B.; Li, D.; Liu, G.; Zhou, W.; Zhang, Y.-X. Modulating the Balance of Synaptic and Extrasynaptic NMDA Receptors Shows Positive Effects against Amyloid- $\beta$-Induced Neurotoxicity. J. Alzheimer's Dis. 2017, 57, 885-897. [CrossRef]

78. Miyamoto, T.; Stein, L.R.; Thomas, R.; Djukic, B.; Taneja, P.; Knox, J.; Vossel, K.; Mucke, L. Phosphorylation of tau at $Y 18$, but not tau-fyn binding, is required for tau to modulate NMDA receptor-dependent excitotoxicity in primary neuronal culture. Mol. Neurodegener. 2017, 12, 41. [CrossRef]

79. Monteiro-Fernandes, D.; Silva, J.; Soares-Cunha, C.; Dalla, C.; Kokras, N.; Arnaud, F.; Billiras, R.; Zhuravleva, V.; Waites, C.; Bretin, S.; et al. Allosteric modulation of AMPA receptors counteracts Tau-related excitotoxic synaptic signaling and memory deficits in stress- and A $\beta$-evoked hippocampal pathology. Mol. Psychiatry 2020, 1-13. [CrossRef]

80. Ittner, L.M.; Ke, Y.D.; Delerue, F.; Bi, M.; Gladbach, A.; Van Eersel, J.; Wölfing, H.; Chieng, B.C.; Christie, M.J.; Napier, I.A.; et al. Dendritic Function of Tau Mediates Amyloid- $\beta$ Toxicity in Alzheimer's Disease Mouse Models. Cell 2010, 142, 387-397. [CrossRef]

81. Decker, J.M.; Krüger, L.; Sydow, A.; Dennissen, F.; Siskova, Z.; Mandelkow, E.; Mandelkow, E. The Tau/A152T mutation, a risk factor for frontotemporal-spectrum disorders, leads to NR 2B receptor-mediated excitotoxicity. EMBO Rep. 2016, 17, 552-569. [CrossRef] [PubMed]

82. Wang, R.; Reddy, P.H. Role of Glutamate and NMDA Receptors in Alzheimer's Disease. J. Alzheimer's Dis. 2017, 57, 1041-1048. [CrossRef] [PubMed]

83. Bartus, R.; Dean, R.; Beer, B.; Lippa, A. The cholinergic hypothesis of geriatric memory dysfunction. Science 1982, 217, 408-414. [CrossRef] [PubMed]

84. Simon, D.; Hernandez, F.; Ávila, J. The Involvement of Cholinergic Neurons in the Spreading of Tau Pathology. Front. Neurol. 2013, 4, 74. [CrossRef] [PubMed]

85. Kamynina, A.V.; Holmstrom, K.; Koroev, D.O.; Volpina, O.M.; Abramov, A.Y. Acetylcholine and antibodies against the acetylcholine receptor protect neurons and astrocytes against beta-amyloid toxicity. Int. J. Biochem. Cell Boil. 2013, 45, 899-907. [CrossRef]

86. Ishii, M.; Hiller, A.J.; Pham, L.; McGuire, M.J.; Iadecola, C.; Wang, G. Amyloid-Beta Modulates Low-Threshold Activated Voltage-Gated L-Type Calcium Channels of Arcuate Neuropeptide Y Neurons Leading to Calcium Dysregulation and Hypothalamic Dysfunction. J. Neurosci. 2019, 39, 8816-8825. [CrossRef]

87. Furukawa, K.; Wang, Y.; Yao, P.J.; Fu, W.; Mattson, M.P.; Itoyama, Y.; Onodera, H.; D'Souza, I.; Poorkaj, P.H.; Bird, T.D.; et al. Alteration in calcium channel properties is responsible for the neurotoxic action of a familial frontotemporal dementia tau mutation. J. Neurochem. 2003, 87, 427-436. [CrossRef] 
88. Lawlor, B.; Segurado, R.; Kennelly, S.; Rikkert, M.O.; Howard, R.J.; Pasquier, F.; Börjesson-Hanson, A.; Tsolaki, M.; Lucca, U.; Molloy, D.W.; et al. Nilvadipine in mild to moderate Alzheimer disease: A randomised controlled trial. PLoS Med. 2018, 15, e1002660. [CrossRef]

89. Abdullah, L.; Crawford, F.; Tsolaki, M.; Börjesson-Hanson, A.; Rikkert, M.O.; Pasquier, F.; Wallin, A.; Kennelly, S.; Ait-Ghezala, G.; Paris, D.; et al. The Influence of Baseline Alzheimer's Disease Severity on Cognitive Decline and CSF Biomarkers in the NILVAD Trial. Front. Neurol. 2020, 11, 149. [CrossRef]

90. Hwang, D.; Kim, S.; Choi, H.; Oh, I.-H.; Kim, B.S.; Choi, H.R.; Kim, S.Y.; Won, C. Calcium-Channel Blockers and Dementia Risk in Older Adults - National Health Insurance Service - Senior Cohort (2002-2013). Circ. J. 2016, 80, 2336-2342. [CrossRef]

91. Feldman, L.; Vinker, S.; Efrati, S.; Beberashvili, I.; Gorelik, O.; Wasser, W.; Shani, M. Amlodipine treatment of hypertension associates with a decreased dementia risk. Clin. Exp. Hypertens. 2016, 38, 545-549. [CrossRef] [PubMed]

92. Bohlken, J.; Jacob, L.; Kostev, K. The Relationship Between the Use of Antihypertensive Drugs and the Incidence of Dementia in General Practices in Germany. J. Alzheimer's Dis. 2019, 70, 91-97. [CrossRef] [PubMed]

93. Stutzmann, G.E.; Smith, I.; Caccamo, A.; Oddo, S.; Parker, I.; LaFerla, F. Enhanced Ryanodine-Mediated Calcium Release in Mutant PS1-Expressing Alzheimer's Mouse Models. Ann. New York Acad. Sci. 2007, 1097, 265-277. [CrossRef] [PubMed]

94. Paula-Lima, A.C.; Adasme, T.; Sanmartín, C.; Sebollela, A.; Hetz, C.; Carrasco, M.A.; Ferreira, J.; Hidalgo, C. Amyloid $\beta$-Peptide Oligomers Stimulate RyR-Mediated Ca2+ Release Inducing Mitochondrial Fragmentation in Hippocampal Neurons and Prevent RyR-Mediated Dendritic Spine Remodeling Produced by BDNF. Antioxid. Redox Signal. 2011, 14, 1209-1223. [CrossRef]

95. DeMuro, A.; Parker, I. Cytotoxicity of intracellular a 342 amyloid oligomers involves Ca2+ release from the endoplasmic reticulum by stimulated production of inositol trisphosphate. J. Neurosci. 2013, 33, 3824-3833. [CrossRef]

96. Cheung, K.-H.; Shineman, D.; Müller, M.; Cárdenas, C.; Mei, L.; Yang, J.; Tomita, T.; Iwatsubo, T.; Lee, V.M.-Y.; Foskett, J.K. Mechanism of Ca2+ Disruption in Alzheimer's Disease by Presenilin Regulation of InsP3 Receptor Channel Gating. Neuron 2008, 58, 871-883. [CrossRef]

97. Bojarski, L.; Pomorski, P.; Szybinska, A.; Drab, M.; Skibinska-Kijek, A.; Gruszczynska-Biegala, J.; Kuźnicki, J. Presenilin-dependent expression of STIM proteins and dysregulation of capacitative Ca2+ entry in familial Alzheimer's disease. Biochim. Biophys. Acta 2009, 1793, 1050-1057. [CrossRef]

98. Tong, B.C.-K.; Lee, C.S.-K.; Cheng, W.-H.; Lai, K.-O.; Foskett, J.K.; Cheung, K.-H. Familial Alzheimer's disease-associated presenilin 1 mutants promote $\gamma$-secretase cleavage of STIM1 to impair store-operated Ca2+entry. Sci. Signal. 2016, 9, ra89. [CrossRef]

99. Ye, J.; Yin, Y.; Yin, Y.; Zhang, H.; Wan, H.; Wang, L.; Zuo, Y.; Gao, D.; Li, M.; Li, J.; et al. Tau-induced upregulation of C/EBP $\beta$-TRPC1-SOCE signaling aggravates tauopathies: A vicious cycle in Alzheimer neurodegeneration. Aging Cell 2020, e13209. [CrossRef]

100. Mata, A.M. Functional interplay between plasma membrane Ca 2+-ATPase, amyloid $\beta$-peptide and tau. Neurosci. Lett. 2018, 663, 55-59. [CrossRef]

101. Berrocal, M.; Sepulveda, M.R.; Vazquez-Hernandez, M.; Mata, A.M. Calmodulin antagonizes amyloid- $\beta$ peptides-mediated inhibition of brain plasma membrane Ca2+-ATPase. Biochim. Et Biophys. Acta (BBA)—Mol. Basis Dis. 2012, 1822, 961-969. [CrossRef] [PubMed]

102. Wu, A.; A Derrico, C.; Hatem, L.; A Colvin, R. Alzheimer's amyloid-beta peptide inhibits sodium/calcium exchange measured in rat and human brain plasma membrane vesicles. Neuroscience 1997, 80, 675-684. [CrossRef]

103. Pannaccione, A.; Piccialli, I.; Secondo, A.; Ciccone, R.; Molinaro, P.; Boscia, F.; Annunziato, L. The $\mathrm{Na}+/ \mathrm{Ca} 2+$ exchanger in Alzheimer's disease. Cell Calcium 2020, 87, 102190. [CrossRef] [PubMed]

104. Atherton, J.; Kurbatskaya, K.; Bondulich, M.; Croft, C.L.; Garwood, C.J.; Chhabra, R.; Wray, S.; Jeromin, A.; Hanger, D.P.; Noble, W. Calpain cleavage and inactivation of the sodium calcium exchanger-3 occur downstream of A $\beta$ in Alzheimer's disease. Aging Cell 2013, 13, 49-59. [CrossRef]

105. Kip, S.N.; Strehler, E.E. Rapid downregulation of NCX and PMCA in hippocampal neurons following $\mathrm{H} 2 \mathrm{O} 2$ oxidative stress. Ann. New York Acad. Sci. 2007, 1099, 436-439. [CrossRef] 
106. Ferreira, A.; Bigio, E.H. Calpain-Mediated Tau Cleavage: A Mechanism Leading to Neurodegeneration Shared by Multiple Tauopathies. Mol. Med. 2011, 17, 676-685. [CrossRef]

107. Liang, B.; Duan, B.-Y.; Zhou, X.-P.; Gong, J.-X.; Luo, Z.-G. Calpain Activation Promotes BACE1 Expression, Amyloid Precursor Protein Processing, and Amyloid Plaque Formation in a Transgenic Mouse Model of Alzheimer Disease. J. Boil. Chem. 2010, 285, 27737-27744. [CrossRef]

108. Rao, M.; McBrayer, M.K.; Campbell, J.; Kumar, A.; Hashim, A.; Sershen, H.; Stavrides, P.H.; Ohno, M.; Hutton, M.; Nixon, R.A. Specific Calpain Inhibition by Calpastatin Prevents Tauopathy and Neurodegeneration and Restores Normal Lifespan in Tau P301L Mice. J. Neurosci. 2014, 34, 9222-9234. [CrossRef]

109. Reinecke, J.B.; Devos, S.L.; McGrath, J.P.; Shepard, A.M.; Goncharoff, D.K.; Tait, D.N.; Fleming, S.R.; Vincent, M.; Steinhilb, M.L. Implicating Calpain in Tau-Mediated Toxicity In Vivo. PLoS ONE 2011, 6, e23865. [CrossRef]

110. O'Day, D.H.; Eshak, K.; Myre, M.A. Calmodulin Binding Proteins and Alzheimer's Disease. J. Alzheimer's Dis. 2015, 46, 553-569. [CrossRef]

111. Esteras, N.; Alquézar, C.; De La Encarnación, A.; Villarejo, A.; Bermejo-Pareja, F.; Requero, A.M. Calmodulin levels in blood cells as a potential biomarker of Alzheimer's disease. Alzheimer's Res. Ther. 2013, 5, 55. [CrossRef] [PubMed]

112. Esteras, N.; Dinkova-Kostova, A.T.; Abramov, A.Y. Nrf2 activation in the treatment of neurodegenerative diseases: A focus on its role in mitochondrial bioenergetics and function. Boil. Chem. 2016, 397, 383-400. [CrossRef] [PubMed]

113. Petersen, C.A.H.; Alikhani, N.; Behbahani, H.; Wiehager, B.; Pavlov, P.F.; Alafuzoff, I.; Leinonen, V.; Ito, A.; Winblad, B.; Glaser, E.; et al. The amyloid -peptide is imported into mitochondria via the TOM import machinery and localized to mitochondrial cristae. Proc. Natl. Acad. Sci. USA 2008, 105, 13145-13150. [CrossRef] [PubMed]

114. Pavlov, P.F.; Wiehager, B.; Sakai, J.; Frykman, S.; Behbahani, H.; Winblad, B.; Ankarcrona, M. Mitochondrial $\gamma$-secretase participates in the metabolism of mitochondria-associated amyloid precursor protein. FASEB J. 2010, 25, 78-88. [CrossRef] [PubMed]

115. Cieri, D.; Vicario, M.; Vallese, F.; D’Orsi, B.; Berto, P.; Grinzato, A.; Catoni, C.; De Stefani, D.; Rizzuto, R.; Brini, M.; et al. Tau localises within mitochondrial sub-compartments and its caspase cleavage affects ER-mitochondria interactions and cellular Ca2+ handling. Biochim. Et Biophys. Acta (Bba) 2018, 1864, 3247-3256. [CrossRef]

116. Amadoro, G.; Corsetti, V.; Stringaro, A.; Colone, M.; D’Aguanno, S.; Meli, G.; Ciotti, M.; Sancesario, G.; Cattaneo, A.; Bussani, R.; et al. A NH2 Tau Fragment Targets Neuronal Mitochondria at AD Synapses: Possible Implications for Neurodegeneration. J. Alzheimer's Dis. 2010, 21, 445-470. [CrossRef]

117. Abramov, A.Y.; Duchen, M.R. Mechanisms underlying the loss of mitochondrial membrane potential in glutamate excitotoxicity. Biochim. Biophys. Acta (BBA) 2008, 1777, 953-964. [CrossRef]

118. Duchen, M. Mitochondria and Ca2+in cell physiology and pathophysiology. Cell Calcium 2000, 28, 339-348. [CrossRef]

119. Abramov, A.Y.; Canevari, L.; Duchen, M.R. $\beta$-Amyloid Peptides Induce Mitochondrial Dysfunction and Oxidative Stress in Astrocytes and Death of Neurons through Activation of NADPH Oxidase. J. Neurosci. 2004, 24, 565-575. [CrossRef]

120. Stout, A.K.; Raphael, H.M.; Kanterewicz, B.I.; Klann, E.; Reynolds, I.J. Glutamate-induced neuron death requires mitochondrial calcium uptake. Nat. Neurosci. 1998, 1, 366-373. [CrossRef]

121. Pivovarova, N.B.; Nguyen, H.V.; Winters, C.A.; Brantner, C.A.; Smith, C.L.; Andrews, S.B. Excitotoxic Calcium Overload in a Subpopulation of Mitochondria Triggers Delayed Death in Hippocampal Neurons. J. Neurosci. 2004, 24, 5611-5622. [CrossRef] [PubMed]

122. Qiu, J.; Tan, Y.-W.; Hagenston, A.M.; Martel, M.-A.; Kneisel, N.; Skehel, P.A.; Wyllie, D.J.; Bading, H.; Hardingham, G.E. Mitochondrial calcium uniporter Mcu controls excitotoxicity and is transcriptionally repressed by neuroprotective nuclear calcium signals. Nat. Commun. 2013, 4, 4. [CrossRef] [PubMed]

123. Angelova, P.R.; Vinogradova, D.; Neganova, M.E.; Serkova, T.P.; Sokolov, V.V.; Bachurin, S.O.; Shevtsova, E.F.; Abramov, A.Y. Pharmacological Sequestration of Mitochondrial Calcium Uptake Protects Neurons Against Glutamate Excitotoxicity. Mol. Neurobiol. 2018, 56, 2244-2255. [CrossRef] [PubMed] 
124. Sanz-Blasco, S.; Valero, R.A.; Rodríguez-Crespo, I.; Villalobos, C.; Nuñez, L. Mitochondrial Ca2+ Overload Underlies A $\beta$ Oligomers Neurotoxicity Providing an Unexpected Mechanism of Neuroprotection by NSAIDs. PLoS ONE 2008, 3, e2718. [CrossRef] [PubMed]

125. Sanz-Blasco, S.; Calvo-Rodriguez, M.; Caballero, E.; García-Durillo, M.; Nuñez, L.; Villalobos, C. Is it All Said for NSAIDs in Alzheimer's Disease? Role of Mitochondrial Calcium Uptake. Curr. Alzheimer Res. 2018, 15, 504-510. [CrossRef]

126. Calvo-Rodriguez, M.; Hou, S.S.; Snyder, A.C.; Kharitonova, E.K.; Russ, A.N.; Das, S.; Fan, Z.; Muzikansky, A.; Garcia-Alloza, M.; Serrano-Pozo, A.; et al. Increased mitochondrial calcium levels associated with neuronal death in a mouse model of Alzheimer's disease. Nat. Commun. 2020, 11, 1-17. [CrossRef]

127. Jadiya, P.; Kolmetzky, D.W.; Tomar, D.; Di Meco, A.; Lombardi, A.A.; Lambert, J.; Luongo, T.S.; Ludtmann, M.H.; Praticò, M.; Elrod, J.W. Impaired mitochondrial calcium efflux contributes to disease progression in models of Alzheimer's disease. Nat. Commun. 2019, 10, 3885. [CrossRef]

128. Csordás, G.; Várnai, P.; Golenár, T.; Roy, S.; Purkins, G.; Schneider, T.G.; Balla, T.; Hajnóczky, G. Imaging Interorganelle Contacts and Local Calcium Dynamics at the ER-Mitochondrial Interface. Mol. Cell 2010, 39, 121-132. [CrossRef]

129. Del Prete, D.; Suski, J.M.; Oulès, B.; Debayle, D.; Gay, A.S.; Lacas-Gervais, S.; Bussiere, R.; Bauer, C.; Pinton, P.; Paterlini-Bréchot, P.; et al. Localization and Processing of the Amyloid- $\beta$ Protein Precursor in Mitochondria-Associated Membranes. J. Alzheimer's Dis. 2016, 55, 1549-1570. [CrossRef]

130. Area-Gomez, E.; Schon, E.A. On the Pathogenesis of Alzheimer's Disease: The MAM Hypothesis. FASEB J. 2017, 31, 864-867. [CrossRef]

131. Hedskog, L.; Pinho, C.M.; Filadi, R.; Rönnbäck, A.; Hertwig, L.; Wiehager, B.; Larssen, P.; Gellhaar, S.; Sandebring, A.; Westerlund, M.; et al. Modulation of the endoplasmic reticulum-mitochondria interface in Alzheimer's disease and related models. Proc. Natl. Acad. Sci. USA 2013, 110, 7916-7921. [CrossRef] [PubMed]

132. Zampese, E.; Fasolato, C.; Kipanyula, M.J.; Bortolozzi, M.; Pozzan, T.; Pizzo, P. Presenilin 2 modulates endoplasmic reticulum (ER)-mitochondria interactions and Ca2+ cross-talk. Proc. Natl. Acad. Sci. USA 2011, 108, 2777-2782. [CrossRef] [PubMed]

133. Kipanyula, M.J.; Contreras, L.; Zampese, E.; Lazzari, C.; Wong, A.K.C.; Pizzo, P.; Fasolato, C.; Pozzan, T. $\mathrm{Ca} 2+$ dysregulation in neurons from transgenic mice expressing mutant presenilin. Aging Cell 2012, 11, 885-893. [CrossRef] [PubMed]

134. Tu, H.; Nelson, O.; Bezprozvanny, A.; Wang, Z.; Lee, S.-F.; Hao, Y.-H.; Serneels, L.; De Strooper, B.; Yu, G.; Bezprozvanny, I. Presenilins Form ER Ca2+ Leak Channels, a Function Disrupted by Familial Alzheimer's Disease-Linked Mutations. Cell 2006, 126, 981-993. [CrossRef] [PubMed]

135. Shilling, D.; Mak, D.-O.D.; Kang, D.E.; Foskett, J.K. Lack of Evidence for Presenilins as Endoplasmic Reticulum Ca2+Leak Channels. J. Boil. Chem. 2012, 287, 10933-10944. [CrossRef]

136. Parks, J.K.; Smith, T.S.; A Trimmer, P.; Bennett, J.P.; Parker, W.D. Neurotoxic A $\beta$ peptides increase oxidative stress in vivo through NMDA-receptor and nitric-oxide-synthase mechanisms, and inhibit complex IV activity and induce a mitochondrial permeability transition in vitro. J. Neurochem. 2001, 76, 1050-1056. [CrossRef]

137. Abramov, A.Y.; Fraley, C.; Diao, C.T.; Winkfein, R.; Colicos, M.A.; Duchen, M.R.; French, R.J.; Pavlov, E. Targeted polyphosphatase expression alters mitochondrial metabolism and inhibits calcium-dependent cell death. Proc. Natl. Acad. Sci. USA 2007, 104, 18091-18096. [CrossRef]

138. Britti, E.; Ros, J.; Esteras, N.; Abramov, A.Y. Tau inhibits mitochondrial calcium efflux and makes neurons vulnerable to calcium-induced cell death. Cell Calcium 2020, 86, 102150. [CrossRef]

139. Du, H.; Guo, L.; Fang, F.; Chen, D.; A Sosunov, A.; McKhann, G.M.; Yan, Y.; Wang, C.; Zhang, H.; Molkentin, J.D.; et al. Cyclophilin D deficiency attenuates mitochondrial and neuronal perturbation and ameliorates learning and memory in Alzheimer's disease. Nat. Med. 2008, 14, 1097-1105. [CrossRef]

140. Kopach, O.; Esteras, N.; Wray, S.; Rusakov, D.A.; Abramov, A.Y. Maturation and phenotype of pathophysiological neuronal excitability of human cells in tau-related dementia. J. Cell Sci. 2020, 133, jcs241687. [CrossRef]

141. Esteras, N.; Rohrer, J.D.; Hardy, J.; Wray, S.; Abramov, A.Y. Mitochondrial hyperpolarization in iPSC-derived neurons from patients of FTDP-17 with 10+16 MAPT mutation leads to oxidative stress and neurodegeneration. Redox Boil. 2017, 12, 410-422. [CrossRef] [PubMed] 
142. Bartolome, F.; Esteras, N.; Martin-Requero, A.; Boutoleau-Bretonnière, C.; Vercelletto, M.; Gabelle, A.; Le Ber, I.; Honda, T.; Dinkova-Kostova, A.T.; Hardy, J.; et al. Pathogenic p62/SQSTM1 mutations impair energy metabolism through limitation of mitochondrial substrates. Sci. Rep. 2017, 7, 1666. [CrossRef] [PubMed]

143. Delgado-Camprubi, M.; Esteras, N.; Soutar, M.P.M.; Plun-Favreau, H.; Abramov, A.Y. Deficiency of Parkinson's disease-related gene Fbxo7 is associated with impaired mitochondrial metabolism by PARP activation. Cell Death Differ. 2016, 24, 120-131. [CrossRef] [PubMed]

144. Abramov, A.Y. Actions of ionomycin, 4-BrA23187 and a novel electrogenic $\mathrm{Ca} 2+$ ionophore on mitochondria in intact cells. Cell Calcium 2003, 33, 101-112. [CrossRef]

145. Zamaraeva, M.V.; Hagelgans, A.I.; Abramov, A.Y.; Ternovsky, V.I.; Merzlyak, P.G.; Tashmukhamedov, B.A.; Saldkhodzjaev, A.I. Ionophoretic properties of ferutinin. Cell Calcium 1997, 22, 235-241. [CrossRef]

(C) 2020 by the authors. Licensee MDPI, Basel, Switzerland. This article is an open access article distributed under the terms and conditions of the Creative Commons Attribution (CC BY) license (http://creativecommons.org/licenses/by/4.0/). 